Copyright (C) 2019 by Academic Publishing House Researcher

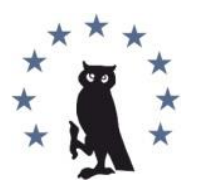

Published in the Russian Federation

European Researcher. Series A

Has been issued since 2010.

E-ISSN 2224-0136

2019, 10(4): 230-236

DOI: $10.13187 / \mathrm{er} .2019 .4 .230$

www.erjournal.ru

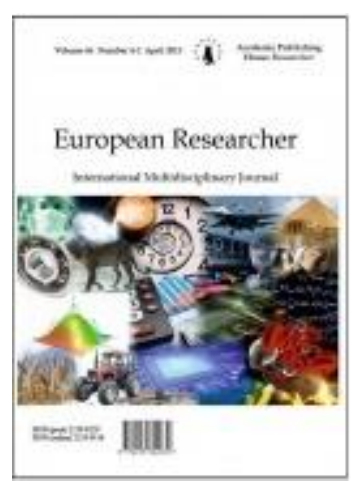

\title{
Afghan Women's Viewpoint about Bringing Peace and Security in Afghanistan with Emphasis on Regional Convergence*
}

\author{
Shogofa Sahar a , *, Filiz Katman a \\ a Istanbul Aydin University, Istanbul, Turkey
}

\begin{abstract}
This article examines the issue of Afghan peace from the perspective of Afghan women with regard to regional convergence. The research method of this article is descriptive using library resources. It is the belief of Afghan women to adopt strategic regional strategies to secure peace in Afghanistan. Regional convergence and cooperation, which is one of the strategies for enabling peace in Afghanistan, believes Afghan women can secure peace in Afghanistan and the region. They believe that the peace of Afghanistan is the peace of the region, because the focus of regional and global actors on Afghanistan and its geostrategic position has given rise to any disturbances first in Afghanistan and later in the region. Years of insecurity and disorder in Afghanistan are the most appropriate ground for the supporters of terrorism. Eventually, regional actors exploited structural insecurity and instability in Afghanistan and pursued their hegemonic demands in the region by financing terrorism and developing insecurity in Afghanistan. In this context, Afghan women argue that the best solution to tackling insecurity and suppressing terrorism is regional convergence and cooperation.
\end{abstract}

Keywords: peace, security, Afghan women, regional convergence.

\section{Introduction}

In the present globalized era and due to the consumption of land resources in many developed countries of the world, they have become scarce. As these countries have consumed their resources, other emerging powers have managed and are progressing. The progress of these countries and the lack of resources of the superpowers have given rise to a sense of competition with the emerging powers and their suppression by the superpowers. Lack of energy and hegemonic credibility are a series of factors that trigger regional games and take over strategic points in the region (Mohammadi, 2018: 3).

The United States and some other countries in the world and in the region seeking to compete with emerging Asian powers from China to safeguard their hegemonic credibility and alliance with strategic Asian nations to meet this target of terrorism and some Other disorders are taken for granted. As many of its countries, including Afghanistan, for some reason have not developed and their natural resources remain intact, the availability of resources in Afghanistan and at the same time its strategic location is important to regional and global actors. So the

\footnotetext{
* This article is based on the dissertation of Shogofa Sahar Master's Thesis entitled Afghan Women's Viewpoint about Bringing Peace and Security in Afghanistan with Emphasis on Regional Convergence.

${ }^{*}$ Corresponding author

E-mail addresses: shogofa.sahar@gmail.com (S. Sahar), filizkatman@aydin.edu.tr (F. Katman)
} 
presence of global actors in the region and in Afghanistan has affected the situation and security of Afghanistan (Mohammadi, 2018: 3).

As a result, competition for hegemonic credibility, competition for the alliance of countries with abundant natural resources, competition for domination of strategic and pioneering positions in the world have made a number of global players in the region noticeable. This is why the years of war and insecurity in Afghanistan are the same, and this war and insecurity in Afghanistan is the best opportunity for global actors, including the United States. The US military presence in Afghanistan under the pretext of securing peace and war on terror is one of the factors for which the US wants to maintain its hegemonic credentials and not lose resources to Afghanistan and the region. On the other hand, the presence of US troops in Afghanistan means keeping the emerging Asian powers under control. So all of these issues somehow play a role in creating and developing insecurity in Afghanistan (Mohammadi, 2018: 4).

So terrorism in Afghanistan is dependent on the foreign policy of some regional and global countries that have failed to support terrorism in Afghanistan for their strategic plans (Shafei, 2009: 8; Sattari, 2002: 19). Because of Afghanistan's strategic position, Afghan peace can be termed regional peace (Javadi, 2008: 18), so regional convergence and cooperation can play a key role in securing Afghanistan's peace and regional peace. The Taliban and ISIL terrorist groups, which exist in most parts of Afghanistan, are also threatening the borders, specially the countries of Central Asia and other countries in the region. The greater degree of regional coordination and integration, make the risk of terrorist groups developing less in the region. In fact, regional cooperation in Afghanistan, which is an international issue, will also eliminate terrorism in Afghanistan.

The insecurity of Afghanistan is one of the factors that has severely damaged various classes, including the female class. From women's citizenship rights to their mental health, they are all affected by insecurity in Afghanistan. The Afghan government has been trying to fulfill its longstanding dream of peace for many years, but it is not easy. So the continued insecurity in Afghanistan has caused the most legal and psychological damage to women. Widows, childbearing, loss of a brother and other by insecurity in Afghanistan are among the injuries that have targeted the female class. So this article examines the peace and security of Afghanistan from the women's viewpoint. It is the belief of Afghan women that Afghanistan's peace will be secured if there is no support for terrorism by regional integration.

Now, on the basis of the aforementioned topics, we would like to explore Afghanistan's peace with regional integration from afghan women's viewpoint.

\section{Discussion}

\section{Conceptual Framework}

Insecurity in Afghanistan

Insecurity in Afghanistan has been institutionalized since the formation of the Taliban terrorist group and has taken on a more complex form since the suppression of the Taliban regime on September 11, 2001. Since the global policies of some countries have prevented the removal of terrorism from Afghanistan, after 2014 until now, terrorist groups are better funded and supported. Alongside the Taliban terrorist group, ISIL has also formed secret subgroups involved in disrupting Afghan security.

Afghanistan's civil wars began in the wake of al-Qaeda's attack on New York and Washington on September 9, led by Osama bin Laden. Afterwards, US President George W. Bush warned the Taliban to hand over the al-Qaeda terrorist group to Afghanistan. Following the Taliban's refusal to accept the US request, an order was issued on October 5 to officially declare a long-term operation of freedom. The United Kingdom began its independent military operations in the year 5 . The main purpose of this war was to fight and eliminate al-Qaeda, the Taliban and its supporters (CBA News. Associated Press).

Almost a month later, the Taliban regime collapsed and came to power with the conquest of President Hamid Karzai and was elected president in Afghanistan. The war left tens of thousands of civilian casualties. More than three ISAF soldiers and civilian contractors, four Afghan National Security Forces, and more than 6,00o civilians were killed. After five years of continuous war, on December 2, NATO and the United States officially ended their combat operations in Afghanistan and left all security responsibilities to the Afghan government. Thus, a new era of warfare in Afghanistan 
has begun so far. The existence of terrorist groups in Afghanistan not only threatens its security, but the development of these groups is a regional and global threat (The Guardian, 2014).

\section{Convergence}

Convergence is the process by which loyalty from one center (government) to another center or centers is shifted. In general, convergence theorists believe that countries will develop convergent behavior when they anticipate shared opportunities and facilities, as well as depend on the ability to internalize the convergence process (Duerti, Faltzgraf, 2011: 214).

\section{Theoretical Framework (Regional security complex)}

Patterns of relations between countries in the Central and South Asian region are important issues that illustrate the security structure of the region and the way governments in these countries view environmental security issues. The high level of competition and tension in relations between the countries of the region is a sign of the deep security concerns of neighbors over each other and the dominance of the competitive atmosphere between them. Therefore, studying the patterns of relations between these countries and the context of such a pattern is of great importance in analyzing the structure of this region (Sazmand, Mehdi, 2016: 7).

At the same time, the existence and multiplicity of regional and global actors in the region require better relations with neighbors. Given the current political and hegemonic tensions in the region and Afghanistan's historical differences with some of its neighbors, the theory of regional security complexes fits well with the subject of this article.

The emphasis on the regional level as one of the key levels of analysis in security issues has long been the focus of security studies researchers. The regions, which have become increasingly important in international relations since the end of the decolonization and their independence from European multipolar structure as one of the main subsystems, have become increasingly important to them since the end of the Cold War. An important level of security analysis has been added to international relations, and, as Acharya puts it, an increasing demand for Third World regional security arrangements is emerging as a feature of the post-Cold War security agenda (Sazmand, Mehdi, 2016: 8).

With the publication of Buzan's book (People, Governments, and Panic), the security agenda in security theory entered a new phase. According to Buzan, the events of the end of the Cold War in the international system have brought both new dimensions of security and security authority to governments and to transnational and transnational actors. He believes that macro-level and micro-level analysis cannot account for changes in security dimensions and reference.

Barry Buzan and Al Weaver, in their joint book, "Regions and Powers," published in Year 2, claim that the security of any country does not depend solely on itself and cannot be relied solely on the national level in the analysis of security. On the other hand, the global level is also very general and lacks an understanding of security for countries. They therefore present the regional level as the level of appropriate analysis. Buzan and Weaver argue that in order to prevent the overdefinition of security, the hierarchy of levels of analysis within the international system must be considered, each of which is viable, important, and contains features that make it self-sufficient security. That is to say, their security issues should be specific to the role of foreign actors (Sazmand, 2016: 9).

Within the framework of regional security set theory, most of the processes of securitization and non-security appear in clusters of regional sets. On the other hand, regional security features are enduring. These features are essentially self-sustaining, not because they are independent, but because they have a security dynamic that exists even without the influence of other actors.

Accordingly, the regional level is emphasized as the level of principal analysis in the theory of regional security complex. Buzan therefore defines a regional security complex as a set of units in which major security and non-security processes, or both, are so intertwined that security problems cannot be analyzed or resolved separately.

The basic structure of a security complex has four variables: the border, which separates the regional security complex from its neighbors; the anarchic structure, meaning that the regional security complex must consist of two or more autonomous units; Power is distributed among units; social construction involves patterns of friendship and hostility among units. Despite the four main variables that make up a security complex, Buzan also refers to an external factor as "intrusion" or "cover", which, although not inherent in a regional security complex, can internalize a complex and even make changes to it (Sazmand, Mehdi, 2016: 9). 
Based on this theory, Afghanistan's insecurity depends on how some of its neighbors and trans-regional actors operate, and regional integration must be promoted to secure Afghanistan. And the principle of friendship - hostility, too. That is, regional animosities must become friendships.

\section{Regional convergence as a factor in peacebuilding}

In the wake of increasing cross-border transactions, communications, and connections of different kinds between different states, the boundaries of their authorities will be changed and the feature of their societies will become more and more likewise. The more this kind of feeling spreads across the member-nations in individual and social levels, the more and the better their way will be paved towards creating a bloc, a cluster, or a subordinate system, distinguishing them from the rest of the system. Undoubtedly the efforts made by governments to redraw boundaries of their authority and to expand it at the regional level will have a huge impact on political map of each region and will consequently lead to economic, and social consequences. And in the final analysis it is this interaction and intercourse between these clusters of nations by which the future of each individual state and the future of the region as a whole will be shaped. Any regional arrangement consists of a number of players and actors, big and small, who are acting individually or in form of groups and blocs according to a set of common norms, interests and concerns. For this common interests and concerns to form and establish and to be defined, there must be a minimum sense of community between those nations which are about to be parts of this integration (Higgott, 2006: 31).

Karl Deutsch defines this sense of community as an essential element in the concept of integration. According to him integration is defined as a matter of mutual sympathies and loyalty; of 'we-feeling', trust, and mutual consideration; of partial identification in terms of semi images and interests; of mutually successful predictions of behavior, and of cooperative action in accordance with it (Deutsch, 1957: 36). In other words, one can argue that the following phases must happen in order we can achieve the basis upon which the regional integration can be built:

1. Developing a common understanding about each other, and about the region, and developing a genuine and natural empathy towards each other in a way that each nation feels and perceives other nation's pain and misery or joy and prosperity as its own.

2. Making sure that all members do stay loyal to each other and will never betray each other no matter what is the circumstances.

3. Reassuring the fact that in spite of the different nationalities, ethnic roots, and religions they belong to, still they can enjoy a deep and meaningful sense of oneness which gives them a sense of common identity above all others.

4. Trying to expand bilateral and multilateral sense of trust, faith and confidence towards each other which makes it easy to cooperate with each other.

5. Attempting to increase their similarities in terms of their expectations and the way they see and perceive the threats and challenges, and then respectively their proposed policies and plans to solve them (Khani, 2018: 12).

It is not difficult to imagine how different countries which adhere above points and pass the above stages successfully can facilitate their move towards regional integration. However, it seems that there must be a minimum level of above factors available for starting the process of regional integrations, and then as the result of the ongoing process, if successful, these five issues will reach to a maximum level. The nations engaged in integration process usually start this process by trying it in just a few fields and then gradually these limited areas can and will lead to a wider range of other fields from security to political relations, from agriculture to culture, from environment and energy to transport and trade etc. As the time passes by, and as the new concerns emerge, the new areas of cooperation and competition begin to come into sight. Hence, that durability, consistency and stability of any integration attempt which demonstrates itself in a regional bloc and organization does depend to great extent on how the lines of cooperation and competition between players will be defined and drawn. It is very important that the members of these new communities learn and accept that cooperation and competition do work at the same time in a healthy manner. Since in regional integration these lines are defined on the most natural commonality between the member states, therefore the risk of collapse and disintegration becomes less and less (Gause, 2014: 21).

Relying on the practical basis of regional integration and cooperation, Afghanistan is one of the countries with a geopolitical position in the region and its security is of paramount importance 
in the regional and global relations of Asian countries. Afghanistan is a country that connects Central Asia and South Asia, so the better Afghanistan's communication space with the countries of the region is, more geopolitical and cyber for situation of the region. Actually by Afghanistan security the regional communications will be more balanced. As terrorism is increasing on a daily basis due to some disturbances in the Afghan government and disruption to Afghan foreign policy, regional integration and counterterrorism cooperation are ideal ways to eliminate terrorism in Afghanistan and providing security to the region (Amini, 2009: 46).

\section{Afghan women's viewpoint about peace of Afghanistan}

What is clear, shows that the goodness of life in a safe and comfortable space. Experimental records and previous studies conclude that human life takes on a real meaning with peace and security, and in the existence of security, human minds are healed and biological well-being is provided. Many developing countries, which have a lot of natural resources but have not been able to achieve development, may not have had good security, so it was not possible to plan development projects and implement them in such communities. One of the most resource-rich countries is Afghanistan, which has failed to experience social and economic growth due to the existence of war and hypocrisy in its history.

In today's age when globalization has brought many developments around the world, Afghanistan, with a history of war, internal and external divisions has failed to take advantage of globalization in recent decades. In the absence of peace and security and the continued existence of socioeconomic disruption in Afghanistan, the most vulnerable category has been the female class. The existence of distortions in Islamic principles and misconceptions about women's rights have led Afghan women to be held captive by extremist delusions for many years.

From the denial of women's citizenship to the stoning of women, they are all rooted in the misrepresented beliefs of Islamic extremists who do not understand Islam properly and, incidentally, these Islamic extremists constitute terrorist groups in Afghanistan that also contribute to Afghanistan's internal insecurity. Despite this, although a series of changes have been made in Afghanistan's social status and status of women, Afghan women still find peace and security a way to access their human rights in order to be fully free from the yoke of ignorance and shortsightedness. The function of women, as they are responsible for building human minds and nurturing effective human resources, views peace as a social requirement for fulfilling their human and sexual mission.

Every person in Afghanistan is hungry for peace, so do women of Afghanistan. Despite of experiencing a difficult situation in Afghanistan, Afghan women who have actually suffered the most during Taliban regime, are still hoping for security and peace in the country, even if it is to sign a peace agreement with Taliban. But with one condition, not to allow turning back the clock and reverse our 18 years gains in democracy and women's rights. Considering the fact that, women of Afghanistan have been harmed the most during Taliban regime, they must be given opportunity to take significant part during Peace Negotiation Process. Their voices need to be heard and their demands need to be acknowledged. Believing in Afghan women is the key to securing peace in Afghanistan through genuine unity and the unity of the existing ethnic groups and parties in Afghanistan, undeniably, women have crucial role in this regard as well as in the civilization of a nation.

Afghan women believe that Afghanistan government should make its foreign relations more peaceful than its neighbors and the region in peacekeeping, and that some countries, such as Pakistan and Iran, which have political and economic problems with Afghanistan, should consider the Afghan government. They have defensive and restrictive policies.

At the same time, the development of security processes within Afghanistan is the requirements that Afghan women emphasize. Afghan women see the evolution of government and good governance as a factor in ensuring peace and security in Afghanistan, under which both the Afghan domestic community and the external and international relations of Afghanistan are controlled.

Afghan women believe that if peace is restored in Afghanistan, they will be able to present an efficient and transformative generation to Afghan society using nurturing and motivational skills. Alleyways and back streets threaten security in Afghan cities and Afghan children cannot access schools and universities with full freedom, but their education still emphasize the role of women in 
their lives. Given, amidst all the hardships, Afghan women still have hope, providing peace and security in Afghanistan for better days.

Afghan women consider their only legal deprivation during the turmoil caused by the war in Afghanistan as the only way to bring peace to Afghanistan is regional integration and cooperation with neighboring countries to eliminate terrorist groups. They have come to realize that regional games and the multiplicity of trans-regional actors in the region and their abuses of the situation in Afghanistan have had a direct impact on Afghan security. So the most important way to bring peace to Afghanistan is to help neighboring countries with the principle of regional integration (Mohammadi, 2018: 24).

\section{Conclusion}

According to historical evidence and experience, peaceful relations between countries can be achieved through dynamic and friendly foreign policy on the part of countries in the region. As Afghanistan, with its strategic position in the region (Mojtahedzadeh, 2008: 13), is affected by the foreign policies of some regional and trans-regional countries, regional integration is the only factor that can cut off the roots of terrorism and its support lines in Afghanistan. Because Afghanistan's geopolitics and its political impotence have attracted the attention of many regional and global actors, regional convergence remains a factor that prevents some regional and transregional actors from exploiting common regional opportunities.

Due to the widespread insecurity in Afghanistan, the female cohort has suffered severe injuries. Afghan women have been denied many of their rights in the absence of peace and security. From the civil rights of women to the very nature of their personality and authority, everyone has been under pressure. The insecurity of Afghanistan has also damaged the mental state of women. The severity of insecurity in Afghanistan has taken their mourning children, husbands, brothers and other family members away. So Afghan women's view of Afghanistan's peace and regional peace, which is bitterly insecure, is the most appropriate measure to improve regional relations and regional integration. Indeed, regional integration can achieve the dream of peace in Afghanistan and in the region.

Afghan women continue to believe that the recruitment of Afghan women into national and international affairs can improve and enhance the dynamics of Afghanistan's foreign relations with many regional and trans-regional countries. Project communication with international organizations and sending women to increase their support could open a new way for foreign aid to Afghanistan. In this respect, the ability of women in the international coordination and reconciliation sectors is acknowledged. Therefore, Afghanistan's international affairs and peacebuilding work with regional integration and regional integration through the use of womenfriendly communication and communication skills.

\section{References}

Abdollah Khani, 2005 - Abdollah Khani Ali (2005). International Security: Opportunities, Threats, and Challenges for the National Security of the Islamic Republic of Iran, Tehran: Abrar Contemporary Institute.

Amini, 2009 - Amini Nader (2009). Report: The Situation of Afghanistan and Its Impact for International Peace and Security. Strategic Studies of the Islamic World.

Ansari, 2002 - Ansari Farouq (2002). Political and Social Developments in Afghanistan, Tehran, Ministry of Foreign Affairs.

CBA News. Associated Press - CBA News. Associated Press, U.S. formally ends the war in Afghanistan. [Electronic resource]. URL: https://www.cbsnews.com/news/america-formally-endsthe-war-in-afghanistan (retrieved 28 December 2014).

Duerti, Faltzgraf, 2011 - Duerti James, Faltzgraf Robat (2011). Conflict Theories in International Relations, translated by Alireza Tayeb and Wahid Bozorgi, Tehran, Qomes Publishing.

Gause, 2014 - Gause III F. Gregory (2014). Beyond Sectarianism: The New Middle East Cold War, Brookings Doha Center Analysis Paper, Number 11.

Higgott, 2006 - Higgott, R. (2006). The Theory and Practice of Region: The Changing Global Context, in Regional Integration in East Asia and Europe Convergence or Divergence? By Bertrand Fort and Douglas Webber, London: Routledge. 
Javadi, 2008 - Javadi Mohammad Jafar (2008). Taliban Mobility and its Impact on Pakistan, Afghanistan and US Relations.

Khani, 2018 - Khani Mohammad Hassan (2018). Geopolitics of Regionalism; Moving towards Regional Integration as a Means for Lasting Peace and Stability in the Middle East, Geopolitics Quarterly, Volume: 13, No 4, Winter.

Mohammadi, 2018 - Mohammadi Khodabakhsh (2018). Afghan Peace and Security in Relation to Regional Security, Kabul, Afghanistan Daily, No. 1234.

Mojtahedzadeh, 2008 - Mojtahedzadeh Pirouz (2008). West Asian Security in Geopolitics of the 21st Century, West of Asia, International System and Regional Convergence, Tehran: Institute for Cultural and Social Studies.

Mottaki, 2001 - Mottaki Ibrahim (2001). US Military Attack on Afghanistan: Goals and Outcomes. Journal of Political Science, No. 15.

Safavi, 2010 - Safavi Seyyed Yahya Rahim (2010). US Goals in Military Invasion of Afghanistan. Human Geography Quarterly, No. 3.

Sattari, 2002 - Sattari Sajjad (2002). Intervention in Afghanistan: American Strategic Considerations and Benefits. Regional Studies Quarterly, No. 11.

Sazmand, Mehdi, 2016 - Sazmand Bahar, Mehdi Jokar (2016). Regional Security Complex; Persian Gulf Countries Dynamics and Patterns, Tehran. Geopolitical Quarterly, Vol. 12, Is. 2.

Shafei, 2009 - Shafei Nozzar (2009). Power Reproduction in Afghanistan: Explaining the Taliban's Empowerment. Central Eurasia Studies Quarterly, Second Year, No. 4.

The Guardian, 2014 - The Guardian (28 December 2014). Une Engel Rasmussen in Kabul "Nato ends combat operations in Afghanistan". [Electronic resource]. URL: https://www.the guardian.com/world/2014/dec/28/nato-ends-afghanistan-combat-operations-after-13-years, Retrieved on 11 January 2015. 